\title{
KESAKSIAN ANGGOTA TUBUH DI HARI KIAMAT PERSPEKTIF TAFSIR SAINS
}

\author{
Rizki Pauziah Siregar \\ Institut Dirosat Islamiyah Al-Amien (IDIA) Prenduan \\ Email: riskipauziah@gmail.com
}

\begin{abstract}
Testimony is a statement made by a witness who saw the incident by himself and was at the scene at that time. Nothing can escape this evidence in the afterlife, nor can it be manipulated in the slightest. So the source of the problem that will be discussed is how to witness the body and the interpretation of the rationality of the testimony of the limbs in QS. Yasin: 65. The research approach used by the author is a qualitative approach and is more inclined to follow library research and uses thematic analysis methods, this research will rely on the interpretation of AlJawahir Fi Tafsiril Qur'an by Tantawi Jauhari and books. as primary sources, research journals, and research theses as secondary sources. And what is relevant to this research, the results of the testimony of the limbs according to tantawi Jauhari are that the limbs will testify and it is not only in the afterlife, the body can testify against its owner. but even in the law that applies in the world, the limb that can be used to prove it, to reveal a crime such as murder or abuse. Here the limbs are like hands, it can help to expose the crime. One of them uses a
\end{abstract}


Volume 3, Number 1, Januari - Juli 2021

e-ISSN 2716-4241

ISSN 2723-2344

DNA or fingerprint test, and only Allah will see what the testimony on the Day of Judgment is.

Keywords:Testimony, Members of the Body, Science Interpretation

\section{Abstrak}

Kesaksian adalah suatu pernyataan yang diucapkan oleh seorang saksi (orang yang melihat suatu kejadian dengan matanya sendiri dan berada di tempat kejadian pada saat itu). Tidak ada yang bisa lolos dari kesaksian tersebut ketika di akhirat, juga tidak bisa dimanipulasi sedikit pun. Jadi sumber masalah yang akan dibahas adalah Bagaimana kesaksian tubuh dan penafsiran rasionalits kesaksian anggota tubuh dalam QS.Yasin:65. Adapun pendekatan penelitian yang digunakan penulis yaitu pendekatan kualitatif dan lebih condong untuk mengikuti penelitian kepustakaan (library research) dan menggunakan metode analisis tematik, penelitian ini akan bertumpu pada tafsir Al-Jawahir Fi Tafsiril Qur'an Karya Tantawi Jauhari serta buku sebagai sumber primer, jurnal- jurnal penelitian, dan tesis penelitian sebagai sumber skunder. Dan yang relevan terhadap penelitian ini hasilnya kesaksian anggota tubuh menurut tantawi jauhari ialah bahwasanya, anggota tubuh itu akan bersaksi dan itu bukan cuman ada di akhirat, tubuh bisa bersaksi terhadap diri pemiliknya. tetapi dalam hukum yang berlaku di dunia pun, sekarang anggota tubuh bisa digunakan kesaksiannya, untuk mengungkap sebuah tindak kejahatan seperti pembunuhan atau pelecehan. Disini anggota tubuh 
Rizki Pauziah, Kesaksian Anggota Tubuh di Hari Kiamat Perspektif Tafsir Sains

seperti tangan, itu bisa membantu untuk mengungkap pelaku kejahatan tersebut. Salah satunya ialah dengan memanfaatkan tes DNA atau sidik jari, dan hanya Allah yang mengetahui seperti apa kesaksian di hari kiamat tersebut.

Kata Kunci: Kesaksian, Anggota Tubuh, Tafsir Sains

\section{PENDAHULUAN}

Kesaksian adalah suatu hal yang begitu sering didengar dan dialami oleh manusia dalam kehidupannya di dunia, namun kebanyakan kesaksian yang terjadi di dunia itu penuh dengan kejahatan, sering dimanipulasi, banyak kebohongan yang terjadi padanya, dan menutup rapat kebenaran, berbeda halnya dengan kesaksian di akhirat yaitu kehidupan yang bebas dari tipu daya dan kebohongan.

Ketika kiamat atau hari akhir datang, pada saat itu semua makhluk akan musnah dan punah. Kiamat adalah peristiwa yang akan terjadi dan tidak ada yang tahu kapan ia datang dan juga tidak bisa menunda kedatangannya. ${ }^{1}$ Dan memberikan sumpah palsu atau kersaksian palsu adalah salah satu dari golongan yang Allah abaikan ketika hari kiamat

1 Efa ida Amaliyah, "Pesan Moral KiaMat Perspektif AlQur'an,” Jurnal Hermeunetik, vol.7 nomor 2 (Desember 2013), 302. 
kelak, karena sumpah palsu termasuk dosa besar. ${ }^{2}$ selain itu sumpah palsu juga dapat membinasakan diri sendiri.

Kesaksian di akhirat suatu hal yang ditakuti kebanyakan manusia, sebab kesaksian itu yang akan menentukan nasib seseorang. Apakah ia selamat dari pernyataan lisan seorang saksi atau tidak. Lisan memiliki banyak fungsi, bisa digunakan untuk kebajikan seperti makan, menasehati, dan adapun sebaliknya juga bisa digunakan untuk kebatilan seperti berbohong, bersumpah palsu dan menggunjing. Kejahatan lisan sangatlah membahayakan juga dapat mematikan seseorang karena kesaksiaannya ${ }^{3}$ selama berada di dunia.

sebagaimana firman Allah terhadap orang yang suka bersumpah palsu dalam Al-Qur'an surah Al- Imran:77 yang berbunyi:

${ }^{2}$ Dikalustian rizkiputra, "Bahaya Lisan Dan Pencegahannya Dalam Al-Qur'an" (Syarif hidayatullah, 2011), 58.

${ }^{3}$ Ibid., 3-4. 
Rizki Pauziah, Kesaksian Anggota Tubuh di Hari Kiamat Perspektif Tafsir Sains

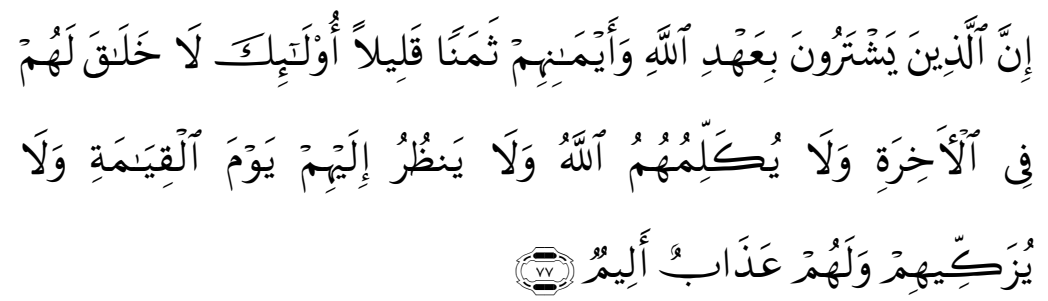

"sesungguhnya orang yang janjinya ia tukar dengan Allah dan sumpahnya ditukar sama harga sedikit, mereka tidak mendapat kebahagiaan diakhirat, dan Allah tidak akan berbicara dengan mereka dan juga tidak akan melihat pada mereka saat kiamat dan tidak pula akan mensucikan mereka, untuk mereka siksa yang pedih”.

Dan adapun ayat yang ada dalam surah yasin ayat 65, yang tercantum dalam al-qur'an sebagai berikut:
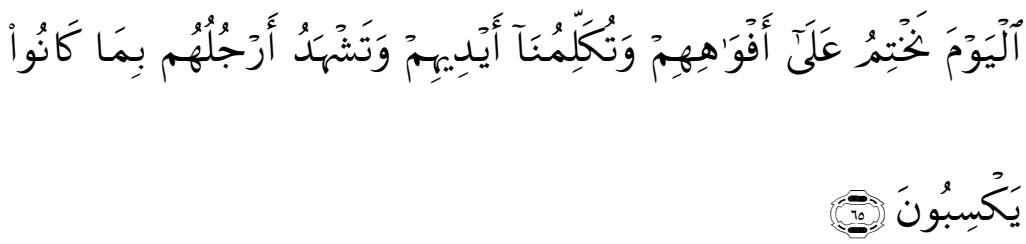

Artinya: "Pada hari ini Kami tutup mulut mereka; dan berkatalah kepada Kami tangan mereka dan memberi kesaksianlah kaki mereka terhadap apa yang dahulu mereka usahakan". 
Kesaksian saat di akhirat, diri sendiri akan bersaksi sebab kesaksiannya itu terjadi atas perintah Allah terhadap mereka, para saksi akan berkata dengan penuh kebenaran dan Allah menjamin serta menutup segala pintu kebohongan, sehingga murni kebenaran yang keluar pada saat itu tanpa ada manipulasi sedikit pun atau konspirasi padanya. ${ }^{4}$ Itu adalah cara Allah yang Maha Kuasa, untuk membuat manusia menanggung apa yang ia perbuat selama hidupnya.

Manusia semestinya memperbaiki diri dengan cara mengaplikasikan kebajikan terhadap diri sendiri. Agar terbebas dari siksaan, dari perbuatan buruk yang setiap hari dibumbui oleh syaithon dan supaya meraih catatan amal dengan tangan kanannya, serta selamat dari introgasi di hari kesaksian kelak, karena setiap perbuatan akan diberikan balasan di hari kiamat oleh Allah. ${ }^{5}$ Sesuai dengan amal perbuatan masing- masing selama berada di dunia.

${ }^{4}$ Kana Rizqina, "Penafsiran Ayat Tentang Hisab Dalam Surat Al-Isra' Ayat 13-14 Dan al-Anbiya Ayat 47" (Aceh: Ar-rainy Darussalam, 2018), 47-48.

5 Amaliyah, "Pesan Moral KiaMat Perspektif Al-Qur'an,” 307. 
Rizki Pauziah, Kesaksian Anggota Tubuh di Hari Kiamat Perspektif Tafsir Sains

\section{PEMBAHASAN TERHADAP KESAKSIAN}

\section{a. Pengertian Kesaksian}

Kata "kesaksian" itu asal kata dari "saksi" yang berarti orang yang melihat suatu peristiwa serta orang yang diturutkan dalam suatu perjanjian. ${ }^{6}$ Sedangkan kesaksian dalam al-qur'an disebut "syahada" (QS. Al-imron) dan adapun Kata "syahida" yang terdapat dalam kamus Mahmud yunus memilik arti menjadi saksi (disisi hakim). ${ }^{7}$ Dan juga berarti menyaksikan dengan mata kepala. ${ }^{8}$

Secara terminologi saksi adalah orang yang melihat suatu kejadian pada waktu kejadian, dan mengetahui sendiri suatu peristiwa tersebut, dan orang yang dapat memberikan penjelasan ketika dibutuhkan. ${ }^{9}$ Sedangkan dalam syar'i ialah sebuah informasi yang disampaikan oleh orang jujur untuk

${ }^{6}$ Plus Partanto, M. Dahlan Barry, Kamus Populer (Surabaya: Arkola, 2001), 696.

${ }^{7}$ Prof.Dr.H.Mahmud Yunus, Kamus Arab- Indonesia (Jakarta: PT.mahmud wadzurriyyah, 2007), 206.

${ }^{8}$ Ahmad Warson Munawwir, Kamus Al- Munawwir ArabIndonesia (Surabaya: Pustaka Progressif, 1997), 747.

${ }^{9}$ Dessy Nurul Nikmah, "Saksi- Saksi Di Hari Kiamat Dalam AlQur'an” (UIN Sunan Ampel Surabaya, 2017), 44-45. 
memberikan bukti kebenaran dengan lafal kesaksian di sebuah majelis persidangan. ${ }^{10}$ Selain itu adapun pendapat dari Quraish Shihab ialah bahwasanya saksi itu seseorang yang mengungkapkan segala yang di saksikannya pada saat itu. $^{11}$

Dari beberapa pengertian yang sudah tercantum di atas, baik dipandang dari pengertian secara etimologis maupun secara terminologi, maka bisa digambarkan dan disimpulkan bahwa saksi itu adalah orang- orang yang menyaksikan, menonton, serta orang yang mengetahui suatu kejadian secara detail, dan saksi berada di lapangan pada saat kejadian berlangsung atau saat terjadinya suatu peristiwa, serta menyatakan semua yang dilihatnya kepada orang yang membutuhkan persaksiannya tersebut di waktu tertentu, tanpa menutupi sedikit hal pun tentang peristiwa yang terjadi.

${ }^{10}$ Nur Aisyah, "Kesaksian Perempuan," Jurnal Al-Qadau, vol.2 Nomor 2 (2015), 177.

${ }^{11}$ Dessy Nurul Nikmah, "Saksi- Saksi Di Hari Kiamat Dalam Al-Qur'an," 44-45. 
Rizki Pauziah, Kesaksian Anggota Tubuh di Hari Kiamat Perspektif Tafsir Sains

\section{b. Urgensi persaksian}

Kesaksian adalah suatu hal yang sangat penting dan dibutuhkan manusia dalam kehidupannya. Baik itu berhubungan dengan manusia maupun dengan tuhan. Di dunia kesaksian sangat penting sebab kesaksian tersebut bisa membantu orang lain atau memojokkan orang lain. Oleh karena itu kesaksian yang dibutuhkan ialah persaksian yang benar. Dalam islam untuk menjadi saksi atau untuk bisa memberikan kesaksian, maka harus memenuhi keenam kriteria syarat sebagai berikut:

1. Seorang saksi harus berakal sehat atau tidak gila

2. Saksi harus balig, kesaksian anak- anak tidak dapat diterima,kecuali dalam kasus yang berhubungan dengan perkara atau permasalahan anak- anak.

3. Harus bisa berbicara atau tidak bisu, karena kesaksian orang bisu tidak dapat diterima walau ia dapat memberi kesaksian dengan isyarat itu juga tetap tidak bisa diterima. Jika kesaksiannya menggunakan tulisan maka bisa saja diterima. 
Volume 3, Number 1, Januari - Juli 2021

e-ISSN 2716-4241

ISSN 2723-2344

4. Saksi haruslah orang muslim, karena dalam al-Qur'an Allah berfirman bahwa saksi yang adil diantara kamu adalah sesama muslim.

5. Mempunyai ingatan yang kuat juga dapat menghafal, dan Memiliki sifat adil. ${ }^{12}$

Akan tetapi jika masalah yang dihadapi berbeda- beda maka saksi yang dibutuhkan pun akan berbeda juga jumlahnya

1. Dalam kasus perzinahan, saksi yang dibutuhkan empat orang, selain dari kasus itu saksi yang dibutuhkan cukup dua orang. Dan jika tentang masalah harta, cukup dua orang perempuan dan satu laki- laki.

2. Jika masalah hukum, saksi cukup satu orang dan sumpah.

${ }^{12}$ Zamzami, “kesaksian Perempuan Dalam Al-qur'an” (UIN Sultan Syarif Kasim Riau, 2011), 21. 
Rizki Pauziah, Kesaksian Anggota Tubuh di Hari Kiamat Perspektif Tafsir Sains

3. Namun, jika masalah kehamilan dan haid, cukup dua orang perempuan sebab hanya perempuanlah yang mengetahuinya, ${ }^{13}$

Dalam memberikan kesaksian, maka sebaiknya seorang saksi mestinya bersaksi dengan kesaksian yang rasional. Agar orang yang mendengarkan mudah memahami dan mengerti. Adapun maksud rasional disini ialah menjelaskan suatu hal dengan penjelasan yang mudah ditanggap atau dipahami oleh akal manusia dan sesuai dengan kenyataan.

\section{c. Kesaksian Yang Diberikan Anggota Tubuh}

Dihari akhirat nanti manusia akan mengalami yang namanya penghisaban dan ketika penghisaban itu dimulai, semua makhluk akan bersaksi atas perkara yang terjadi seperti bumi, langit, dan harta. Maka anggota tubuh yang setia bersama kita juga akan memberikan kesaksiaannya terhadap segala pekerjaan yang telah dilakukan semasa kehidupan di dunia.

${ }^{13}$ Ibid., 17. 
Setiap anggota tubuh yang Allah ciptakan pada diri manusia seperti tangan, kaki, dan lidah akan bisa berbicara lalu diintrogasi, sehingga mereka (tubuh) memberikan kesaksian atau pernyataan terhadap semua perbuatan yang dilakukan oleh tuannya ketika di dunia. Manusia dapat berbohong, akan tetapi ketika anggota tubuh yang bersaksi, maka Pada saat itu juga ketakutan menyelimuti diri manusia, menyesakkan hati manusia. ${ }^{14}$

Ketika itu masing- masing jiwa akan datang dan memperjuangkan diri mereka sendiri agar terhindar dari azab yang begitu pedih. Dengan adanya bukti dan kesaksian yang dipersaksikan, maka manusia tidak akan bisa mengilak atau bersembunyi karena mulut telah dikunci dan segala amal perbuatan telah ditulis di buku catatan masing- masing.

\section{PENGERTIAN TAFSIR SAINS}

Adapun yang dimaksud dengan tafsir sains ialah suatu tafsiran seorang mufassir dalam menjelaskan atau menghubungkan ayat- ayat kauniyah yang ada dalaam al-

${ }^{14}$ Dessy Nurul Nikmah, "Saksi- Saksi Di Hari Kiamat Dalam Al-Qur'an," 61-62. 
Rizki Pauziah, Kesaksian Anggota Tubuh di Hari Kiamat Perspektif Tafsir Sains

qur'an dengan penemuan ilmu sains, yang tujuannya untuk menunjukkan kemukjizatan yang dimiliki al-qur'an, dalam bidang ilmu modern dan membuat manusia semakin memahami keistimewaan yang dimiliki al-Qur'an. ${ }^{15}$ Adapun maksud sains disini ialah ilmu pengetahuanalam seperti ilmu astronomi, biologi, kimia, matematika, dan lain sebagainya. ${ }^{16}$

Adapun ayat- ayat kauniyah ialah ayat al-qur'an yang terkandung didalamnya ilmu kealaman, kemukjizatan dan isyarat ilmiah. Dalam al-qur'an terdapat begitu banyak sekitar 750 ayat kauniyyah, yang membahas berbagai persoalan kehidupan yang bersangkutan dengan alam. ${ }^{17}$

Dan disini penulis akan membahas penafsiran surah yasin ayat 65 , dimana ayat ini menjelaskan tentang anggota tubuh yang bersaksi atas pemiliknya. Adapun kitab yang

15 Mohammad Nor Ichwan, Tafsir Ilmy (Jogjakarta: Menara Kudus Jogja, 2004), 127.

16 Sujiat Zubaidi Saleh, "Epistemologi Penafsiran

Ilmiah Al-Qur'an," Jurnal TSAQAFAH, vol.7 No. 1 (April 2011), 112.

17 Maulidi Ardiyantama, "Ayat-Ayat Kauniyyah Dalam Tafsir Imam Tantowi Dan AL-Razi,” Jurnal Al-Dzikra, vol.11 No 2 (Desember 2017), 190. 
Volume 3, Number 1, Januari - Juli 2021

e-ISSN 2716-4241

ISSN 2723-2344

penulis gunakan adalah salah satu kitab tafsir sains, yaitu $A l$ Jawahir Fi Tafsiril Qur'an Karya Tantawi Jauhari.

\section{BIOGRAFI MUFASSIR TANTAWI JAUHARI}

Syekh Tantawi bin Jauhari Al- Misri adalah nama lengkapnya Tantawi Jauhari. Tantawi lahir pada tahun 1287 $\mathrm{H}$ atau $1826 \mathrm{M}$ di sebuah desa di Mesir, ia adalah anak seorang petani, namun orang tuanya terkenal sebagai tokoh agama di desa mereka. Beliau adalah seorang mufassir yang ahli filsafat, selain itu ia juga dikenal sebagai filosof muslim, beliau adalah seorang tokoh pembaharuan muslim yang menekuni bidang agama juga menekuni bidang ilmu fisika serta bahasa.

Adapun pendidikan Tantawi dimulai di desa Al-Ghar, selain itu ia juga mendapatkan pelajaran dari pamannya syaikh Muhammad Syalabi. Setelah menyelesaikan sekolah di desa Ghar, beliau pun melanjutkan pendidikan di universitas al-Azhar Kairo, disitu ia bertemu dengan banyak tokoh salah satunya ialah Muhammad Abduh beliau adalah dosen Tantawi sekaligus tempat bertukar pikiran dalam segala hal. Dan berhasil menyelesaikan pendidikan di tahun 
Rizki Pauziah, Kesaksian Anggota Tubuh di Hari Kiamat Perspektif Tafsir Sains

1893 M, dan ditahun itu juga karirnya dimulai sebagai pendidik. $^{18}$

Pada tahun 1940 M, Tantawi Jauhari wafat dan selama hidupnya beliau berhasil menulis beberapa karya tulis kurang lebih 30 karya diantaranya:

1. Al-Jawahir Fi Tafsir al-Qur'an al-Karim

2. Al-Qur'an Wa al-'Ulum al-Asy'ariyah

3. Al-Qawaid al- Jauhariyah Fi al-Turuq alNahwiyah

4. Al-Hikmah Wa al-Hukama.

5. Al-Nizam Wa al-Islam

6. Nidzam al- 'Alam Wa al- Umam

7. Aina al-Insan

8. Nizam al-'Alam Wa al-Umam

9. Aslu al-'Alam Qa al-Umam

10. Al-Taj Wa al-Murassa

${ }^{18}$ Abida fikriyah nita, "Penafsiran Tantawi Jauhari Dalam QS Al-Mu'minun: 12-14 Dan Impilikasi Terhadap Teori Evolusi Darwin" (UIN Sunan Ampel Surabaya, 2019), 58-60. 
Volume 3, Number 1, Januari - Juli 2021

e-ISSN 2716-4241

ISSN 2723-2344

11. Bahjah al-Ulum Fi al-Falsafah al-'Arabiyah Wa Muwazanatuha Bi al- 'Ulum al- 'Asriyah. ${ }^{19}$

\section{LATAR BELAKANG PENULISAN KITAB TAFSIR AL- JAWAHIR}

Dalam penulisan tafsir tantawi jauhari, Alasan beliau menyusun karya ini agar masyarakat bisa menyadari bahwa Mempelajari ilmu pengetahuan lain semisal pertanian, matematika, fisika, dan ilmu lainnya itu juga sebuah kewajiban. Selain itu beliau ingin mengungkap beberapa keajaiban, dan keindahan yang ada di alam dengan menggunakan ayat- ayat penjelas yang Allah turunkan.

Tafsir ini ditulis pada saat beliau mengajar di Universitas Dar al- Ulum di Mesir, dan tulisan ini adalah tulisan pertama beliau. Adapun tujuan beliau menulis karya ini untuk membuat umat islam menyenangi dan melakukan beberapa kajian sains atau kealaman. Sehingga islam bisa bangkit dalam berbagai bidang.Dalam kitabnya tantawi metode yang beliau menggunakan ialah tahlili dan corak

$$
{ }^{19} \text { Ibid., } 61 .
$$


Rizki Pauziah, Kesaksian Anggota Tubuh di Hari Kiamat Perspektif Tafsir Sains

penafsiran 'ilmi. Beliau juga menjelaskan dengan begitu rinci dalam tafsirannya. ${ }^{20}$ Beikut ini penafsiran Ayat Kesaksian Dalam Surah Yasin Ayat: 65

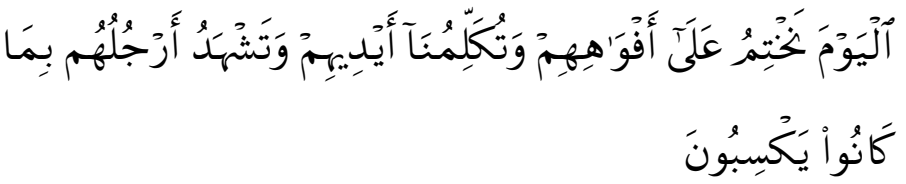

Artinya: Pada hari ini Kami tutup mulut mereka; dan berkatalah kepada Kami tangan mereka dan memberi kesaksianlah kaki mereka terhadap apa yang dahulu mereka usahakan.

Pada hari ini (kiamat) kami akan tutup mulut mereka, kami melarang mereka untuk berbicara, dan tangan mereka akan berkata kepada kami dan juga kaki mereka memberikan kesaksian terhadap semua perbuatan mereka sewaktu di dunia. Pada saat itu mereka mengingkari hari kiamat dan berbantah- bantah lalu bersaksilah tetangga mereka atas mereka, kemudian merekapun bersumpah bahwa mereka bukan dari golongan orang musyrik, sehingga pada saat itu

${ }^{20}$ Armainingsih, "Studi Tafsir Saintifik Al-Jawahir Fi Tafsir Al-Qur' an Al-Karim Karya Syeikh Tantawi Jauhari," Jurnal At-Tibyan, vol.I No.1 (June 2016), 103-105. 
terkuncilah mulut mereka dan berkatalah tangan dan kaki mereka. $^{21}$

Pada saat hari kiamat ada seorang hamba berkata "sesungguhnya aku tidak membolehkan diriku bersaksi kecuali bersaksi atas diriku sendiri, lalu terkuncilah mulut mereka atas apa yang luput padanya dan dikatakanlah kepada anggota badanya untuk berbicara, maka ia pun berbicara dengan apa yang telah ia lakukan, kemudian ia diam.

Dan ketahuilah bahwasanya perkataan ini adalah yang dibenarkan akal dan ilmu pengetahuan, kebenaran diatas kebenaran. Tidakkah kamu melihat bahwa Allah telah mengeluarkanmu dari kebodohan. Manusia di dunia itu berada ditempat yang penuh kebohongan dan kejahatan dan juga kemunafikan yang bersembunyi, dan tampak pada wajahnya yang memerah ketika merasa takut. Maka dari itulah hakim mengambil dalil untuk hukuman terdakwa, dan engkau akan melihat sebagian manusia menggunting dirinya sendiri sebagai pelaku.

${ }^{21}$ Tantawi Jauhari, Al-Jawahir Fi Tafsiril Qur'an (Musthofa Albabi Jalabi, 1348), 146. 
Rizki Pauziah, Kesaksian Anggota Tubuh di Hari Kiamat Perspektif Tafsir Sains

Disitulah tangan- tangan para penjahat terkunci diatas kertas, dan tidak ada yang dapat menyamakan antara tangan yang satu dengan tangan lainnya. Dan jika seseorang mengetahui semua tangan yang ada pada manusia, niscaya kamu tidak akan dapat mengingatnya (mengetahuinya). jika di dunia ini, orang yang berbuat dosa, mendapatkan balasan dan orang yang berbuatan baik, mendapatkan pengaruh baik dari perbuatannya. Akan tetapi bentuk balasan baik dan buruknya itu akan tampak apabila jasad berpisah dengan arwahnya.

Sebagaimana yang dikatakan Allah ta'ala: “bacalah kitabmu, cukuplah dirimu hari ini segala perhitungan atasmu". Maka jika tercatat dalam kitab yang tiada kecurangan didalamnya dan tiada kebohongan. Maka apabila lisan diam, berbicaralah anggota tubuh sebagaimana berbicara yang sempurna dan tandanya lebih sempurna. ${ }^{22}$

${ }^{22}$ Ibid, 147. 


\section{ANALISIS AYAT}

Adapun ayat diatas menjelaskan bahwasanya dihari perhitungan nanti Allah akan menutup mulut manusia, agar tidak bisa berbicara lagi, dan kemudian tangan dan kaki merekalah yang akan berbicara memberikan kesaksian terhadap semua perbuatan mereka sewaktu di dunia. Mulut mereka dikunci sebab mereka mengingkari hari kiamat dan juga berbantah- bantah, ketika tetangga mereka bersaksi atas mereka, kemudian merekapun bersumpah bahwa mereka bukanlah dari golongan yang sama, sehingga pada saat itulah mulut mereka dikunci agar tangan dan kaki mereka bisa bersaksi atas dirinya.

Dan pada hari itu juga seorang hamba meminta agar tidak boleh ada yang bersaksi atas dirinya kecuali dirinya sendiri, lalu permintaan pun diterima dengan cara menutup mulutnya agar tidak ada kebohongan atasnya. Dan ketika di dunia mereka mencoba untuk berbohong, maka ketika itu juga, mereka akan mengalami perubahan pada wajahnya yaitu menjadi memerah, karena mereka dikelilingi rasa takut. 
Rizki Pauziah, Kesaksian Anggota Tubuh di Hari Kiamat Perspektif Tafsir Sains

Takut terbongkar akan segala perbuatan yang sudah diperbuat.

Di dunia saja manusia mengalami perubahan dalam dirinya, dan tanpa disadari perubahan itu menjadi tanda terhadap kebohongan yang terungkap. Apalagi kebohongan ketika di hari kiamat niscaya tidak akan bisa sebab saat itu juga pintu untuk berbohong sudah tertutup rapat tanpa ada celah sedikitpun bagi mereka.

Maka adapun Q.S.fushshilat: 22 disini sebagai penguat dari penjelasan ayat yang tercantum diatas, sebagaimana firman allah:

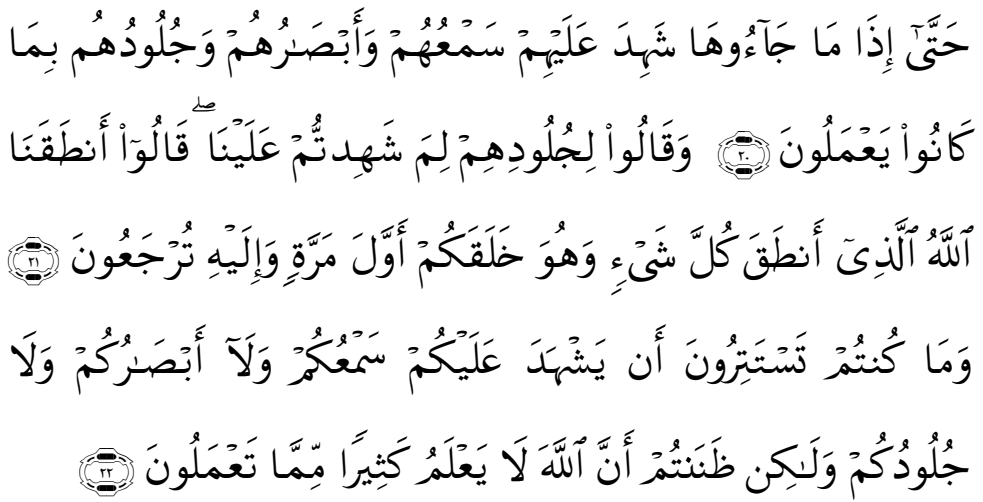

Artinya: Sehingga apabila mereka sampai ke neraka, pendengaran, penglihatan dan kulit mereka menjadi saksi 
terhadap mereka tentang apa yang telah mereka kerjakan. Dan mereka berkata kepada kulit mereka: "Mengapa kamu menjadi saksi terhadap kami?" kulit mereka menjawab: "Allah yang menjadikan segala sesuatu pandai berkata telah menjadikan Kami pandai (pula) berkata, dan Dia-lah yang menciptakan kamu pada kali pertama dan hanya kepada-Nya lah kamu dikembalikan". Kamu sekali-sekali tidak dapat bersembunyi dari kesaksian pendengaran, penglihatan dan kulitmu kepadamu bahkan kamu mengira bahwa Allah tidak mengetahui kebanyakan dari apa yang kamu kerjakan.

Dalam ayat ini menegaskan serta menjelaskan lebih rinci lagi tentang anggota tubuh yang bisa bersaksi, bukan cuman tangan dan kaki yang bersaksi seperti yang tercantum dalam surah Yasin ayat 65, namun ayat itu diperjelas lagi dalam surah Fushshilat dimana indra penglihatan, pendengar, dan kulit sekalipun ikut bersaksi atas dirinya. Allah menurunkan ayat tersebut untuk memperkuat firmannya, agar manusia memahami dan berfikir.

Anggota tubuh yang selama ini digunakan sesuai kehendak pemiliknya selama hidup di dunia, tidak akan pernah berpihak kepadanya lagi dan juga tidak akan menuruti perkataan mulut lagi, karena pada saat hari pembalasan telah 
Rizki Pauziah, Kesaksian Anggota Tubuh di Hari Kiamat Perspektif Tafsir Sains

tiba disana, semua perbuatan akan dihitung dan dipertanggungjawabkan.

Dan bukan cuman di akhirat anggota tubuh bisa bersaksi terhadap diri pemiliknya. Dalam hukum yang berlaku di dunia pun sekarang anggota tubuh telah bisa untuk digunakan kesaksiannya, dan untuk mengungkap sebuah tindak kejahatan seperti pembunuhan atau pelecehan. Disini anggota tubuh seperti tangan, itu bisa membantu untuk mengungkap pelaku kejahatan tersebut. Salah satunya ialah dengan memanfaatkan tes DNA atau sidik jari.

Adapun tes DNA adalah singkatan dari Deoxyribo Nucleic Acid dan sering juga disebut asam kimia yang mengandung informasi dan yang mengatur program keturunan makhluk hidup selanjutnya. DNA ini sangatlah potensial dalam melacak asal- usul keturunan seseorang. ${ }^{23}$ Sedangkan sidik jari adalah hasil reproduksi tapak jari dan tidak ada yang sama antara satu dengan yang lain. Perbedaan

${ }^{23}$ Hilman Ali Fardhinand, "Eksistensi Tes DNA Sebagai Alat Bukti Dalam Pembuktian Hukum Pidana," Jurnal Lex Crimen, vol.2 nomor 2 (April 2015), 199. 
ini yang sangat bermanfaat untuk dipergunakan sebagai alat penyelidik. $^{24}$

Tes DNA dan sidik jari adalah hal yang seringkali dilakukan orang-orang hukum sebagai bantuan dalam mengumpulkan bukti- bukti guna untuk menyelesaikan kasus kriminal yang mereka hadapi. Dengan adanya tes DNA seseorang dapat mengetahui siapa pelaku tersangka, dan bisa mengumpulkan beberapa bukti penguat setelahnya.

Sama halnya dengan sidik jari, ini akan sangat berguna untuk dijadikan sebagai bukti atau saksi bisu dalam pangadilan ketika memutuskan hukum terhadap pelaku kejahatan, sidik jari ini biasanya digunakan pada kasus kejahatan seperti pembunuhan. Jadi sidik jari yang ditinggalkan pelaku sangat berguna untuk melacak keberadaan si penjahat, sebab sidik jari setiap orang berbeda.

${ }^{24}$ Subaidi, "Keabsahan Sidik Jari Sebagai Alat Bukti Dalam Tindak Pidana Perspektif Hukum Islam," Jurnal Cendekia, vol.2 nomor 2 (Desember 2016), 242. 
Rizki Pauziah, Kesaksian Anggota Tubuh di Hari Kiamat Perspektif Tafsir Sains

Wajah adalah salah satu bagian tubuh yang sering menangkap sinyal ketika seseorang berbohong. Dalam ilmu pengetahuan lain juga telah membahas tentang bahasa tubuh manusia ketika orang tersebut berbohong, dimana ketika ia berbohong maka wajahnya akan berubah seketika. Hal ini sesuai dengan perumpamaan kesaksian tubuh di dunia, yang telah terdapat dalam tafsiran Tantawi Jauhari dalam surah Yasin ayat 65 yang tercantum sebelumnya diatas.

Dari beberapa hal yang tercantum diatas saja sudah bisa membuktikan bahwasanya kesaksian anggota tubuh seperti tangan ketika di dunia sudah sangat membantu, dalam mengungkap kelakuan yang telah pemiliknya perbuat. Walaupun mulutnya masih bisa berbicara untuk melakukan pembelaan, namun jika bukti telah terungkap, maka pelaku tidak akan terhindar dari yang namanya jeratan atau hukuman. Hukum di dunia saja sangat di perhatikan dan di takuti oleh manusia, jadi hukum yang ada di hari kiamat tentunya lebih menakutkan dan hanya Allah semata yang mengetahui bagaimana kesaksian yang berlaku disana. 
Apalagi kesaksian yang diberikan oleh anggota tubuh pada saat hari pembalasan dan perhitungan, dimana disitu tidak ada ruang untuk berbohong sebab pada waktu itu juga mulut terkunci, dan anggota tubuh yang lain pun akan leluasa untuk membuka semua perlakuan yang pemiliknya lakukan. Dan anggota tubuhpun akan menjadi saksi atas dirinya sendiri seperti yang telah Allah firmankan dalam surah yasin ayat 65 :

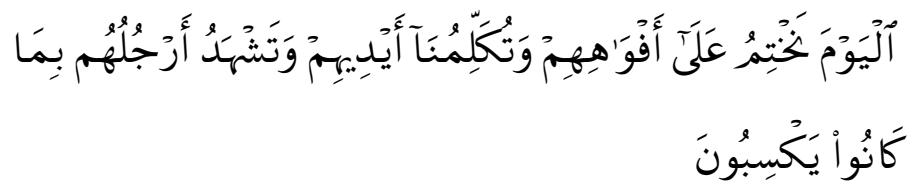

Pada hari ini Kami tutup mulut mereka; dan berkatalah kepada Kami tangan mereka dan memberi kesaksianlah kaki mereka terhadap apa yang dahulu mereka usahakan.

Sebagian besar suatu perbuatan itu dilaksanakan dengan perantaraan tangan, hal ini sesuai dengan dalil alqur'an yang tercantum diatas, selain ayat diatas Allah kembali menegaskan firmannya dengan menurunkan ayat pengingat lainnya ialah:

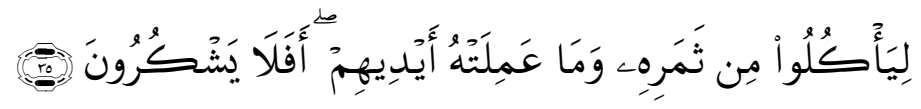


Rizki Pauziah, Kesaksian Anggota Tubuh di Hari Kiamat Perspektif Tafsir Sains

Supaya mereka dapat Makan dari buahnya, dan dari apa yang diusahakan oleh tangan mereka. Maka Mengapakah mereka tidak bersyukur?

Ayat diatas ini sebagai penegas yang Allah turunkan kepada manusia, agar manusia bisa memahami bahwa segala sesuatu yang mereka lakukan dalam kehidupannya. Mereka akan memperoleh buah sesuai dengan perbuatan masingmasing kelak, oleh karena itu bahagia atau tidaknya seseorang itu disebabkan dirinya sendiri. Dan tangan mereka itu akan bercerita semua hal yang pernah dilakukannya semasa hidupnya. ${ }^{25}$

\section{KESIMPULAN}

Pemaparan ayat al-Qur'an diatas dapat disimpulkan bahwasanya, Bukan cuman di akhirat anggota tubuh bisa bersaksi terhadap diri pemiliknya. Namun dalam hukum yang berlaku di dunia pun sekarang anggota tubuh bisa digunakan kesaksiannya, untuk mengungkap sebuah tindak kejahatan manusia seperti pembunuhan atau pelecehan. Disini anggota tubuh seperti tangan, itu sangat bisa membantu untuk

${ }^{25}$ Dessy Nurul Nikmah, "Saksi- Saksi Di Hari Kiamat Dalam Al-Qur'an," 63. 
mengungkap tentang pelaku kejahatan tersebut. Salah satunya ialah dengan memanfaatkan tes DNA atau sidik jari.

Dari beberapa hal yang tercantum diatas saja sudah membuktikan bahwasanya kesaksian anggota tubuh seperti tangan ketika di dunia sudah bisa membantu dalam mengungkap kelakuan yang telah pemiliknya perbuat. Walaupun mulutnya masih bisa berbicara untuk melakukan pembelaan terhadap dirinya, namun jika bukti telah terungkap maka pelaku akan terjerat hukuman juga.

Apalagi kesaksian yang dilakukan oleh anggota tubuh pada saat hari pembalasan dan perhitungan, dimana disitu tidak ada ruang untuk berbohong sebab pada waktu itu juga mulut telah dikunci, dan anggota tubuh yang lain pun akan leluasa untuk membuka semua perlakuan yang pemiliknya lakukan. Ia akan bersaksi atas dirinya sendiri seperti yang telah Allah perintahkan dan hanya Allah yang mengetahui seperti apa kesaksian tersebut. 
Rizki Pauziah, Kesaksian Anggota Tubuh di Hari Kiamat Perspektif Tafsir Sains

\section{DAFTAR PUSTAKA}

Abida fikriyah nita. "Penafsiran Tantawi Jauhari Dalam QS Al-Mu'minun: 12-14 Dan Impilikasi Terhadap Teori Evolusi Darwin.” UIN Sunan Ampel Surabaya, 2019.

Ahmad Warson Munawwir. Kamus Al-Munawwir ArabIndonesia. Surabaya: Pustaka Progressif, 1997.

Amaliyah, Efa ida. "Pesan Moral KiaMat Perspektif AlQur'an." Jurnal Hermeunetik, vol.7 nomor 2 (Desember 2013): 302.

Armainingsih. "Studi Tafsir Saintifik Al-Jawahir Fi Tafsir Al-Qur'an Al-Karim Karya Syeikh Tantawi Jauhari." Jurnal At-Tibyan, vol.I No.1 (June 2016).

Dessy Nurul Nikmah. "Saksi- Saksi Di Hari Kiamat Dalam Al-Qur’an.” UIN Sunan Ampel Surabaya, 2017.

Dikalustian rizkiputra. "Bahaya Lisan Dan Pencegahannya Dalam Al-Qur'an.” Syarif hidayatullah, 2011.

Hakim Syekh Tantawi Jauhari. Al-Jawahir Fi Tafsiril Qur'an. Musthofa Al-babi Jalabi, 1348.

Hilman Ali Fardhinand. "Eksistensi Tes DNA Sebagai Alat Bukti Dalam Pembuktian Hukum Pidana." Jurnal Lex Crimen, vol.2 nomor 2 (April 2015): 199. 
Volume 3, Number 1, Januari - Juli 2021

e-ISSN 2716-4241

ISSN 2723-2344

Kana Rizqina. "Penafsiran Ayat Tentang Hisab Dalam Surat Al-Isra' Ayat 13-14 Dan al-Anbiya Ayat 47." Arrainy Darussalam, 2018.

Maulidi Ardiyantama. "Ayat-Ayat Kauniyyah Dalam Tafsir Imam Tantowi Dan AL-Razi." Jurnal Al-Dzikra, vol.11 No 2 (Desember 2017).

Mohammad Nor Ichwan. Tafsir Ilmy. Jogjakarta: Menara Kudus Jogja, 2004.

Nur Aisyah. "Kesaksian Perempuan." Jurnal Al-Qadau, vol.2 Nomor 2 (2015).

Plus Partanto, M. Dahlan Barry. Kamus Populer. Surabaya: Arkola, 2001.

Prof.Dr.H.Mahmud Yunus. Kamus Arab- Indonesia. Jakarta: PT.mahmud wadzurriyyah, 2007.

Subaidi. "Keabsahan Sidik Jari Sebagai Alat Bukti Dalam Tindak Pidana Perspektif Hukum Islam.” Jurnal Cendikia, vol. 2 nomor 2 (Desember 2016): 242.

Sujiat Zubaidi Saleh. "Epistemologi Penafsiran Ilmiah AlQur'an.” Jurnal Tsaqafah, vol.7 No. 1 (April 2011).

Zamzami. "kesaksian Perempuan Dalam Al-qur'an." UIN Sultan Syarif Kasim Riau, 2011. 